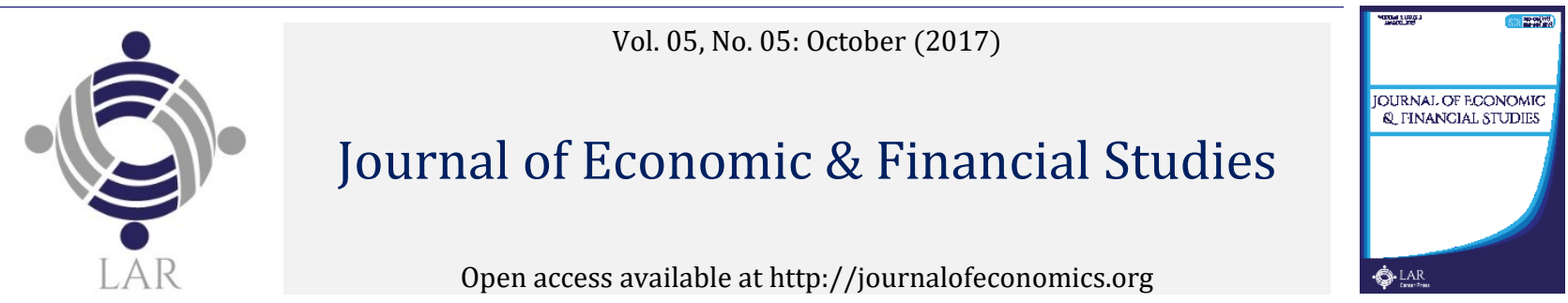

\title{
Inflation targeting and exchange rate pass-through to domestic prices: evidence from South Africa
}

\author{
Oluwasheyi Oladipo ${ }^{a^{*}}$ \\ a SUNY College at Old Westbury, United States. \\ ${ }^{*}$ Corresponding author's email address: oladipos@oldwestbury.edu
}

\section{A R T I C L E IN F O}

Received: 22-08-2017

Accepted: 10-09-2017

Available online: 13-09-2017

Keywords: B22; F41; N00.

JEL Classification :

Inflation targeting ; Pass-through

Prices ; Exchange rate.

\begin{abstract}
A B S T R A C T
Inflation targeting is increasingly seen as a crucial monetary policy by many economies in their quest for economic growth. The choice of an appropriate exchange rate regime, continue to be crucial in macroeconomic policy. Using data from 1970q1 to 2015q4, the paper examines the effects of inflation targeting on exchange rate pass-through. Applying a VAR model, the results show that inflation targeting has significant impacts on the movements of inflation, output and the exchange rate. The pass-through to consumer prices decreased and there was a reduction in the influence of foreign producer costs on imports prices after adopting inflation targeting.
\end{abstract}

(C) 2017 The Authors. This is an open access article under the terms of the Creative Commons Attribution License 4.0, which allows use, distribution and reproduction in any medium, provided the original work is properly cited.

\section{Introduction}

This paper examines the effects of inflation targeting on exchange rate pass-through in South Africa. After the currency crashes of the late 1990s, a growing number of emerging economies moved away from exchange rate rigidity towards a combination of flexible exchange rates and inflation targeting (IT). Inflation targeting is increasingly seen as a crucial monetary policy by these economies in their quest for economic growth. Since exchange rate is a major determinant of inflation, the choice of an appropriate exchange rate regime, and the broad thrust of exchange rate policy continue to be crucial in macroeconomic policy. The nature and timing of linkages among nominal exchange rate, prices and inflation to a large extent determine the effectiveness of the exchange rate policy. Although exchange rate pass-through (ERPT) - the degree to which changes in exchange rates are transmitted to the domestic prices of both tradable and non-tradable goods and services-has been the subject of several empirical studies, the focus has disproportionately been on industrialized countries and studies that have examined the effects of IT on ERPT in developing countries are relatively few.

Exchange rate is one of the macroeconomic fundamentals that significantly affect consumer price inflation. This effect occurs via two channels-direct and indirect. Directly, the exchange rate affects, with a relatively small lag, prices of imported goods, i.e. goods intended directly for the consumer market as well as raw materials and semi-manufactures intended for production of consumer goods of domestic origin. The exchange rate affects not only prices of imported goods, but also-indirectly via import arbitrage-prices of domestic goods which are under competitive pressure from imported goods. With the indirect channel, the change in the exchange rate, all other things being equal, affects the change in the real exchange rate. This, in turn, affects the economy via aggregate demand and a changed output gap. In IT countries, the monetary authority does not directly regulate the exchange rate. However, since changes in the exchange rate also affect inflation, the monetary authority conducts detailed analyses of the exchange rate, and each macroeconomic forecast also contains the internally consistent outlook for the exchange rate. On the one hand, the exchange rate forecast affects future inflation and 
thus also monetary policy, which is aimed at keeping inflation near the inflation target. On the other hand, the exchange rate is in turn affected by monetary policy via the difference between domestic and foreign interest rates.

The choice of the target varies across IT countries. While some have opted for ranges in specifying their inflation targets, others prefer a point target or a point target combined with a range. The trade-off in this regard is essentially between the simplicity of a point target and the degree of flexibility for absorbing shocks outside the control of the authorities which a range target allows. The theoretical and empirical literature suggests that exchange rate fluctuations could significantly affect the level of inflation (Dornbusch, 1987; Krugman, 1987; Menon, 1996; Devereux and Yetman, 2003; Mwase, 2006; Choi and Cook, 2008; Akofio-Sowah, 2009; and Razafimahefa, 2012) especially when a country adopts both a floating exchange rate and open trade policies. An additional advantage of IT is its association with an improvement in overall economic performance also, Bernanke and Mishkin (1997), and Mishkin and Schmidt-Hebbel (2007).

Only two African countries have formally adopted IT-South Africa in 2000, and Ghana in 2007. For a small open economy like South Africa, exchange rate movements are more significant than in advanced industrialized countries as they are likely to have a proportionally greater effect on prices, price competitiveness, resource allocation and output. Before IT, the South African Reserve Bank (SARB) had adopted exchange rate targeting, discretionary monetary policy, and monetary-aggregate targeting at different times between 1960 and 1998. The experience of South Africa can offer valuable lessons to other African countries and small open economies in evaluating the potential costs versus benefits of IT as they consider the inclusion of more liberal trade policies in their economic growth and development plans.

Following this introduction, the paper has five other sections. Section two is an overview of South Africa's experience with inflation targeting, section three discusses the theoretical background and reviews the existing literature on IT and ERPT, section four contains the model and research methodology, section five explains the results and the conclusion is presented in section six.

\section{Exchange rate pass-through and inflation targeting}

Inflation targeting as a formal monetary policy was pioneered in New Zealand in 1990 and has since been adopted by many countries around the world. It involves the declaration of an inflation target, usually a narrow range of inflation rates, by the central bank. The central bank then uses monetary tools, often a policy interest rate, to attempt to keep inflation within the target range. Formal IT adoption stresses increased accountability of the central bank, which must evaluate its performance in meeting the target and publicly disclose the reasons for any deviation.

The effect of nominal exchange rate changes on real exchange rates is directly related to the issue of passthrough from exchange rates to domestic prices. If the inflationary effects of exchange rate changes are large, the authorities will have to implement monetary and fiscal policies to offset the inflationary consequences. A number of studies have shown that ERPT has declined since the 1990s. Taylor (2000) has argued that this lower passthrough has been the result of a decline in the level and volatility of inflation. Accordingly, one of the positive consequences of a strong commitment towards price stability is that ERPT declines significantly, and a virtuous circle develops - lower inflation reduces ERPT, and this in turn helps maintain low inflation. Gagnon and Ihrig (2004) used a sample of advanced countries to analyze the issue, and concluded that the decline in ERPT is related to changes in monetary policy procedures and in particular, to the adoption of IT.

Some studies have suggested that ERPT considerably declines under IT because of the credibility gained by monetary authorities under this policy ${ }^{18}$, and concluded that IT is beneficial. These findings are still a subject of debate and counter debate. Campa and Goldberg (2005) also used data on domestic prices of imports for OECD countries to test Taylor's proposition and their results suggest that monetary conditions are only mildly related to ERPT. Ball and Sheridan (2005:250) stated that "there is no evidence that inflation targeting improves performance as measured by the behavior of inflation, output, or interest rates." They argue that the apparent success of IT countries is simply a reflection of a regression towards the mean; that is, countries that start with higher inflation are more likely to find that inflation will fall faster than countries that begin with an initially low rate of inflation. Since countries that adopted IT generally had higher initial inflation rates, their larger declines in inflation may simply reflect a tendency of all countries, both targeters and non-targeters, to achieve better inflation and output performance in the 1990s when IT was adopted. Ball and Sheridan therefore conclude that, "this finding suggests that better performance resulted from something other than targeting."

\subsection{Inflation targeting in South Africa}

The democratic election of the new government in 1994 marked the end of the apartheid era and coincided with an important shift in South Africa's development strategy, from export promotion with import controls to greater openness through trade liberalization. Also, exchange rate regimes in South Africa have

\footnotetext{
18 The conclusion of a paper Roger and Stone (2005), presented to the Executive Board of International Monetary Fund (IMF). For further evidence, see Coulibaly and Kempf (2010).
} 
evolved from fixed, to managed-floating and more recently to free-floating. These policies have left the country vulnerable to the effects of exchange rate volatility and movements in consumer prices. Changes in exchange rates are important in the determination of monetary policy because they could have major impacts on the price level or inflation. The SARB formally adopted IT on February $23^{\text {rd }}$, 2000. This requires it to announce a numerical point or range target for the inflation rate and to have a strong and credible commitment to price stability, more transparent and clear communication with the public and the markets detailing the instruments that will be used to achieve and maintain the inflation target. The inflation target is set by the government after consultation with the SARB. At the commencement of IT, the SARB announced a target range of 3 to 6 percent for the year-on-year increase in the headline CPIX (CPI for all urban areas) ${ }^{15}$. The specification of the target has been reviewed on a number of occasions over the years. Initially, the target measure was the CPIX, which is defined as the consumer price index for metropolitan and other urban areas. This variant of the CPI was chosen because the overall CPI at the time was influenced directly by changes in the Bank's monetary policy. Following the revisions to the methodology used to compile the CPI, which resulted in a change in the treatment of housing, mortgage interest costs no longer needed to be removed from the CPI when evaluating the effects of monetary policy.

Figure 1: Inflation in South Africa: 2000m1 to 2016m1

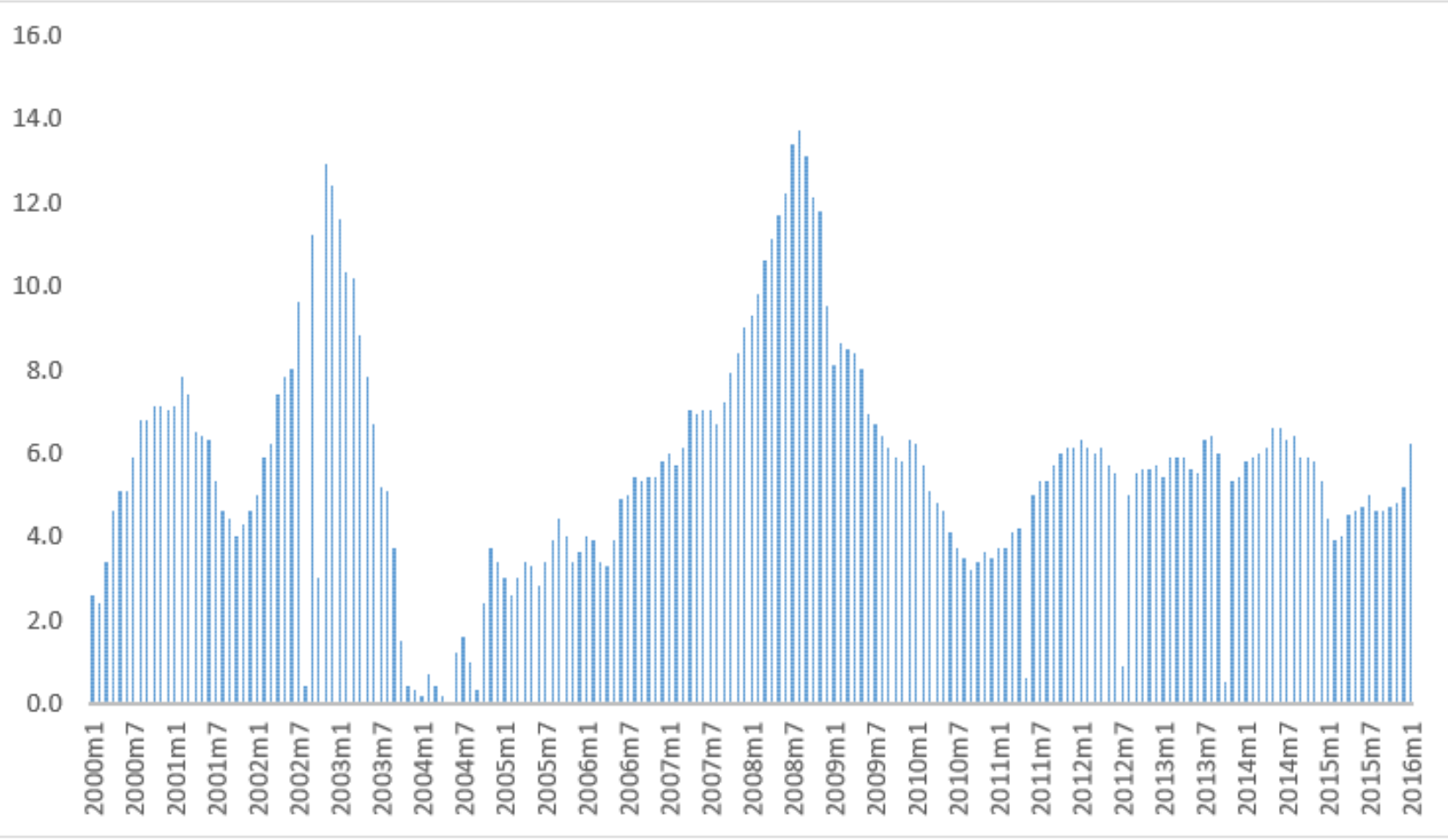

Source: Author

Although the SARB has to a large extent fulfilled its IT mandate, it is a continuing challenge. In recent months, inflation in South Africa has again risen above the target upper bound of 6 percent due to a weak rand, falling oil prices, and high wage demands in the platinum industry. Consumer prices in South Africa went up 6.2 percent year-on-year in January of 2016, accelerating for the fourth straight month and reaching the highest since August of 2014. Figures came above market expectations, due to higher costs for electricity, food, transport and alcoholic beverages. In January 2016, the inflation rate was 6.2 percent after staying within the target entirely in 2015.

\section{Literature review}

A review of the pass-through literature shows that most studies focused on developed countries. Menon (1995b) conducted a comprehensive survey of 43 empirical studies on ERPT in both industrialized and developing countries, but the majority of the surveyed studies were on the USA. The scope of studies on ERPT varies from those analyzing the pass-through of exchange rate fluctuations to import prices, which was the main focus of most early studies (e.g. Menon (1995a), and Goldberg and Knetter (1997)); to those analyzing the passthrough of exchange rate and import price changes to producer and consumer prices (e.g. Bhundia (2002), Devereux and Yetman (2003), Ito and Sato (2007), Karagoz, Demirel and Bozdag (2016), Liu and Chen (2017).

\footnotetext{
${ }^{15}$ At that time, the CPIX inflation was 7 percent. The CPIX is defined as CPI excluding the interest cost of mortgage bonds, for the historical metropolitan and other urban areas. For the credibility of the SARB, as well as the management of expectations, the target rate needs to be set at a level which properly demonstrates a commitment to lowering inflation.
} 
There also have been studies investigating the speed or magnitude and asymmetry of ERPT to import prices (e.g. Feinberg (1989), Kim (1990), Athukorala and Menon (1994), Goldberg and Knetter (1997), Gagnon and Ihrig (2004), Campa and Goldberg (2005) and Karoro et al. (2009)).

Despite the growing literature on ERPT, only a few have focused on South Africa. These include Nell (2000), Bhundia (2002), SARB (2002) and Karoro et al. (2009). Nell (2000) examines the inflationary impact of exchange rate depreciation in South Africa from 1973 to 1998. This period is split into two, 1973 to 1983 and 1984 to 1998, in order to determine whether the underlying causes of inflation changed following significant structural, political and institutional changes, and the adoption of a more market-oriented exchange rate system. Nell (2000:13) formulates price and wage equations which are estimated using distributed lag (DL) and autoregressive distributed lag (ARDL) models. The results suggest that the long-run pass-through estimates are 72 percent and 82 percent in rates of change and levels respectively.

Bhundia's (2002) study focuses on CPIX inflation (see footnote 13), particularly the pass-through profile over the period 2000 to 2001, when monetary policy had the most impact on inflation. Bhundia defines ERPT as the correlation between exchange rate fluctuations and quarterly CPIX inflation. The framework underpinning the analysis is the idea that prices are set along a distribution chain that comprises three stages: importation, production, and consumption. The distribution chain is modeled as a six-variable recursive vector autoregressive (VAR) model. His results indicate that although the average pass-through is low, evidence from the structural VAR model suggests that it is much higher for nominal than real shocks. Exchange rate shocks result in a steady increase over time in the level of the CPIX. The pass-through elasticity resulting from shocks to producer price inflation was approximately 72 percent after eight quarters, suggesting that favorable shocks to producer price inflation could possibly bring CPIX inflation back to target.

SARB (2002) focused on the relationship between changes in the exchange rate and the domestic currency price of imports in South Africa. The methodology is based on Johansen's vector error-correction models (VECM). The results suggest that approximately 78 percent of an exchange rate change is passed through to import prices in South Africa in the long run, and that half of this adjustment occurs in just less than one year. The results suggest further that each month, import prices adjust to equilibrium by approximately 6 percent of any disequilibrium in the long-run relationship.

Karoro et al. (2009) examines the magnitude and speed of ERPT to import, producer and consumer prices in South Africa from 1980 to 2005. It also explores whether the direction and size of changes in the exchange rate have different pass-through effects on import prices, that is, whether the ERPT is symmetric or asymmetric. The paper identifies two main stages of ERPT-the first is the transmission of fluctuations in the exchange rate to import prices, and the second is the pass-through of changes in import prices to producer and consumer prices. The first stage is estimated using Johansen's cointegration and vector error correction model (VECM) techniques. The second stage pass-through is determined by estimating impulse response and variance decomposition functions, as well as conducting block exogeneity Wald tests.

The current study contributes to the literature in a number of ways. First, the study tries to redress the imbalance in country-specific coverage by presenting one of the first estimates on the relationship between ERPT and inflation targeting in South Africa. Second, the sample size is relatively large when compared with sample sizes in previous studies on pass-through and IT for small open economies. Lastly, I use quarterly time series data to reveal the effect of movements in exchange rate on domestic prices of imports, an issue that is most relevant for monetary policy.

\section{Methodology}

The methodology adopted draws from McCarthy (2007), Ito and Sato (2007), and Naqvi and Rizvi (2012). The question is whether the adoption of inflation targeting leads to a corresponding reduction in exchange rate pass-through.

\subsection{The model}

First, the paper examines the pass-through of exchange rate and import price fluctuations denominated in the exporter's currency to domestic consumer prices using a standard VAR model specified as:

$$
X_{t}=\phi+\prod_{1} X_{t-1}+\prod_{2} X_{t-2}+\ldots+\prod_{k} X_{t-k}+\mu_{t}
$$

where $X_{t}$ is a vector of endogenous variables, $\mu_{t}$ is a vector of innovations that may be contemporaneously correlated but are uncorrelated with their own lagged values and also uncorrelated with all other right hand side variables, $\phi$ is a vector of constants and $\Pi$ are matrices of coefficients to be estimated. The baseline model with the vector of five endogenous variables includes output proxied by the index of industrial production $(i p)$, import price $(i m p)$, exchange rate $(e r)$ (this is the nominal effective exchange rate (NEER) which 
represents the domestic price of a basket of currencies ${ }^{19}$ ), domestic prices proxied by the consumer price index (cpi) and interest rate $($ ir $)$. Thus,

$$
X=(\text { ip er impcpiir })^{\prime}
$$

The output gap is derived from the difference between actual and potential output. Potential output is estimated by applying the Hodrick-Prescott (HP) filter to the manufacturing production index. Import price (imp) is included to capture the impact of changes in foreign producer costs on the local currency price of imports, see Campa and Goldberg (2005). Another rationale for the inclusion of this variable is that the price of imports in the local currency depends basically on the price in the foreign currency and the exchange rate. Therefore, controlling for changes in the producer costs allows the isolation of the exchange rate effect. The relationship to be estimated between the reduced-form VAR residuals $\left(\mu_{t}\right)$ and the structural shocks $\left(\varepsilon_{t}\right)$ of the model is:

$$
\left(\begin{array}{l}
\mu_{t}^{i p} \\
\mu_{t}^{e r} \\
\mu_{t}^{i m p} \\
\mu_{t}^{c p i} \\
\mu_{t}^{i r}
\end{array}\right)=\left(\begin{array}{lllll}
s_{11} & 0 & 0 & 0 & 0 \\
s_{21} & s_{22} & 0 & 0 & 0 \\
s_{31} & s_{32} & s_{33} & 0 & 0 \\
s_{41} & s_{42} & s_{43} & s_{44} & 0 \\
s_{51} & s_{52} & s_{53} & s_{54} & s_{55}
\end{array}\right)\left(\begin{array}{l}
\varepsilon_{i}^{i p} \\
\varepsilon_{i}^{e r} \\
\varepsilon_{i}^{i m p} \\
\varepsilon_{i}^{c p i} \\
\varepsilon_{i}^{i r}
\end{array}\right)
$$

The $\varepsilon$ s are contemporaneously uncorrelated, otherwise $s_{i j}$ cannot be identified. The ordered variables are meant to examine the identified shocks contemporaneously, affect their corresponding variable, and those variables that are ordered at a later stage, but have no impact on those that are ordered before ${ }^{20}$.

The industrial output reflects the real sector of the economy while the interest rate is included to examine the impact of monetary policy. The output variable is ordered prior to the exchange rate and domestic prices to allow the exchange rate to respond contemporaneously to the demand shocks in the system. The monetary shock is captured by the change in interest rate and ordered next to allow for a contemporaneous impact of monetary policy shocks on the industrial output and the exchange rate. This ordering is also motivated by the theory that a monetary policy shock would affect prices at different stages contemporaneously and is the main contributing factor to domestic inflation. Thus, the framework is based on the following variable ordering:

$$
I P \rightarrow E R \rightarrow I M P \rightarrow C P I \rightarrow I R
$$

This ordering is based on a progression from the variable that is least exogenous to that which is most exogenous, and is consistent with that in a number of other studies that have used these or similar variables in estimating impulse responses, see McCarthy (2007) and Odria et al. (2012).

\subsection{Data and data sources}

This study uses quarterly time series data from $1970 q 1$ to $2015 q 4$, given the theory that monetary authorities are more interested in short run pass-through dynamics, which are relevant for short term inflation. This sample size of 180 observations is relatively large when compared with sample sizes in previous studies in this area of research. The sample period is divided into pre- and post-inflation targeting periods. The former spans $1970 \mathrm{q} 1$ to $1999 \mathrm{q} 4$ and the latter 2000q1 to $2015 \mathrm{q} 4$. The data were obtained from South African Reserve Bank website, and International Financial Statistics (2016), a publication of the International Monetary Fund. All variables are in real terms.

\section{Estimation results}

\footnotetext{
${ }^{19}$ For South Africa's major trading partners. Because pass-through elasticities may be sensitive to how the nominal exchange rate is defined, I also tried other measures of nominal exchange rate (bilateral versus nominal effective) and the results were similar.

${ }^{20}$ Identification of the structural shock is achieved by appropriately ordering the variables of interest and applying Chol esky decomposition to the variance matrix of the reduced-form residuals $\mu_{t}$. The Cholesky decomposition encompasses the decomposition of the variance covariance matrix $\Omega$ of the reduced-form residuals in a lower triangular matrix $S$. Thus, the $n(n-1) / 2$ economic restrictions are imposed on the triangular matrix to identify the structural shocks, where some of the structural shocks do not have contemporaneous impacts on other variables. $n$ denotes the number of endogenous variables.
} 
Using both the Augmented Dickey-Fuller (ADF) and Phillip-Perron (PP) tests, the null hypothesis of the existence of a unit root was not rejected for the variables in their levels but was rejected in their first differences, providing evidence that the series are integrated of order one, i.e. $I(1)$, at the $5 \%$ significance level, see Table 1.

Table 1: Unit root test results

\begin{tabular}{|c|c|c|c|c|c|c|c|c|}
\hline Variable & \multicolumn{4}{|c|}{ Augmented Dickey Fuller (ADF) Tests } & \multicolumn{4}{|c|}{ Phillips-Perron (PP) Tests } \\
\hline & \multicolumn{2}{|c|}{ Without Trend } & \multicolumn{2}{|c|}{ With Trend } & \multicolumn{2}{|c|}{ Without Trend } & \multicolumn{2}{|c|}{ With Trend } \\
\hline & Level & FD & Level & FD & Level & FD & Level & FD \\
\hline Log of CPI & -2.30 & $-6.54^{*}$ & -2.31 & $-6.57^{*}$ & -2.42 & $-6.57 *$ & -2.47 & $-6.60 *$ \\
\hline Log of IR & -2.23 & $-4.37^{*}$ & -2.37 & $-4.46^{*}$ & -2.26 & $-4.52^{*}$ & -2.34 & $-4.60 *$ \\
\hline Log of ER & 1.27 & $-3.24^{*}$ & -1.31 & $-3.23^{*}$ & 1.68 & $-4.56^{*}$ & 2.21 & $-4.55^{*}$ \\
\hline Log of IP & -0.63 & $-3.90 *$ & -0.62 & $-3.88 *$ & -0.75 & $-4.72 *$ & -0.82 & $-4.70 *$ \\
\hline Log of IMP & -1.37 & $-3.51^{*}$ & -1.48 & $-4.12^{*}$ & -2.03 & $-4.26 *$ & -2.14 & $-4.44^{*}$ \\
\hline
\end{tabular}

Note: * denotes significance at the 5 percent level. Numbers in the Table are the pseudo t- statistics for testing the null hypothesis that the series is nonstationary. The critical values of the ADF and PP statistics with a constant but no trend are $3.47,-2.88$, and -2.57 at the 1,5 and 10 percent significant levels respectively, while the test statistics with a constant and trend are $-4.01,-3.43$, and -3.14 at the 1,5 and 10 percent significance levels respectively.

To ensure that there is no autocorrelation and heteroskedasticity in the residuals, I selected the optimal lag length using the Akaike Information Criterion (AIC) and Hannan-Quinn Information Criterion (HQIC). Table 2 reflects that the optimum lag length is 4 .

Table 2: Lag length selection

\begin{tabular}{lrr}
\hline Lag order & HQIC & AIC \\
\hline 0 & 3.26980 & 3.34564 \\
1 & 3.35781 & 3.56453 \\
2 & 3.26667 & 3.32334 \\
3 & 3.17871 & 3.29668 \\
4 & $2.78967^{*}$ & $3.01432^{*}$ \\
5 & 2.99868 & 3.27846 \\
\hline
\end{tabular}

The existence of a long run relationship exists among the variables is investigated next and both the trace and maximum eigenvalue statistics for the cointegration tests are presented in Table 3 below. The null hypothesis of no cointegration among the variables is rejected using both the $\lambda$-max and the trace statistics, as the eigenvalue and trace test statistics of 34.036 and 71.088 are greater than the critical values of 33.876 and 69.819 respectively at the 5 percent level. This implies that there exists a unique cointegrating vector among the variables involved, and thus, the variables have a finite variance. Dummy variables are included in the VAR to correct for outliers and to reflect the adoption of the structural adjustment program in South Africa in 1990.

Table 3: Johansen cointegration test results

\begin{tabular}{|c|c|c|c|c|c|c|c|}
\hline & & & & ace Test & & num Eigen & lue Test \\
\hline Hypothesized & Eigenvalue & Trace & 0.05 & P-value & Maximum & 0.05 & P-value \\
\hline No. of $\operatorname{CE}(s)$ & & Statistic & Critical & & Eigenvalue & Critical & \\
\hline & & & Value & & Statistic & Value & \\
\hline None* & 0.178596 & 71.08843 & 69.81889 & 0.0395 & 34.03610 & 33.87687 & 0.0479 \\
\hline At most 1 & 0.120971 & 37.05233 & 47.85613 & 0.3451 & 22.30613 & 27.58434 & 0.2051 \\
\hline At most 2 & 0.049342 & 14.74620 & 29.79707 & 0.7963 & 8.753886 & 21.13162 & 0.8518 \\
\hline At most 3 & 0.033215 & 5.992314 & 15.49471 & 0.6965 & 5.843779 & 14.26460 & 0.6334 \\
\hline At most 4 & 0.000858 & 0.148535 & 3.841466 & 0.6999 & 0.148535 & 3.841466 & 0.6999 \\
\hline
\end{tabular}

* denotes rejection of the hypothesis at the 5 percent significance level.

Having established the existence of a unique cointegrating vector, the paper examined the long run relationship among the variables of interest. The dynamics of the long run equilibrium are presented in Tables $4 \mathrm{a}$, $4 \mathrm{~b}$, and $4 \mathrm{c}$. This is of interest because it indicates the behavior of the changes in import prices over time, providing additional information on pass-through. Four lags of each variable are included. The estimated model is specified as:

$$
\begin{aligned}
\Delta \ln I M P_{t}=\propto & +\sum_{\substack{t-1\\
}}^{4} \beta_{1} \Delta \ln I M P_{t-1}+\sum_{t-1}^{4} \beta_{2} \Delta \ln C P I_{t-1}+\sum_{t-1}^{4} \beta_{3} \Delta \ln E R_{t-1}+\sum_{t-1}^{4} \beta_{4} \Delta \ln I P_{t-1}+\sum_{t-1}^{4} \beta_{5} \ln I R_{t-1} \\
& +\beta_{6} E C M_{t-1}+\varepsilon_{t}
\end{aligned}
$$


The equilibrium correction term $\left(E C M_{t-1}\right)$ generated from the cointegration equation is included as an additional channel through which the speed of pass-through can be estimated.

Parsimony was achieved by removing the insignificant regressors and testing the validity of the reduction with an $F$ - test. The parsimonious vector error correction (VECM) was subjected to many diagnostic checks which include stability, within equation residual correlation, heteroskedasticity and normality tests. The serial correlation LM test which can test for higher order ARMA errors show that the residuals do not exhibit autocorrelation. Also, the ARCH LM test for autoregressive conditional heteroskedasticity shows that there is no ARCH in the residuals. For the White's test, the null hypothesis of no heteroskedasticity is accepted. Ramsey's Regression Specification Error Test (RESET) shows that the model is of the correct functional form and that the disturbance vector has the multivariate normal distribution $N\left(0, \sigma^{2}, 1\right)$. A plot of the recursive residuals shows that the residuals are inside the standard error bands suggesting stability in the parameters of the model.

Table 4a: Estimates of the Adjustment to Long Run Equilibrium Relationships-1970q1 to 2015q4) (Dependent Variable: Change in Log of CPI)

\begin{tabular}{|c|c|c|c|c|}
\hline \multicolumn{5}{|c|}{ Data: $1970 q 1$ to $2015 q 4$} \\
\hline Variable & Coefficient & Std. Error & t-value & t-prob \\
\hline DLIMP_2 & -0.3875 & 0.23251 & -2.301 & 0.0122 \\
\hline DLIR_2 & -0.0298 & 0.00642 & -4.645 & 0.0001 \\
\hline DLER_2 & 0.43365 & 0.03652 & 2.671 & 0.0036 \\
\hline DLIP_3 & 0.21237 & 0.01453 & 2.276 & 0.02538 \\
\hline DLCPI_3 & 0.13766 & 0.06035 & 2.1762 & 0.0276 \\
\hline ECM_1 & -0.14567 & 0.02363 & -5.978 & 0.0000 \\
\hline Constant & -0.01822 & 0.0068654 & -2.577 & 0.0015 \\
\hline Seasonal (q1) & 0.0442640 & 0.006942 & 4.313 & 0.0000 \\
\hline Seasonal (q2) & 0.040532 & 0.022789 & 2.0654 & 0.03576 \\
\hline Seasonal (q3) & -0.022349 & 0.011876 & -2.019 & 0.00879 \\
\hline
\end{tabular}

Single Equations Diagnostic Tests ( $\mathrm{p}$-values in parenthesis):

Error auto-correlation $=1280788$ [0.265877]

$\mathrm{ARCH}=1.2327$ [0.26675406]; Heteroskedasticity $=1.15644500$ [0.1878797]

Systems Tests ( $\mathrm{p}$-values in parenthesis):

Error auto-correlation $=1.1325468[0.226734]$

$\mathrm{ARCH}=1.0598706[0.2547340] ;$ Heteroskedasticity $=1.3657987[0.0834532]$

Table 4b: Estimates of the Adjustment to Long Run Equilibrium Relationships-1970q1 to 1999q4 (Dependent Variable: Change in Log of CPI)

\begin{tabular}{|c|c|c|c|c|}
\hline \multicolumn{5}{|c|}{ Data: $1970 \mathrm{q} 1$ to $1999 \mathrm{q} 4$} \\
\hline Variable & Coefficient & Std. Error & t-value & t-prob \\
\hline DLIMP_2 & -0.32953 & 0.15362 & -2.145 & 0.0343 \\
\hline DLIR_2 & -0.41538 & 0.13479 & -3.082 & 0.0026 \\
\hline DLER_3 & 0.42026 & 0.13319 & 3.155 & 0.0021 \\
\hline DLIP_1 & 0.15007 & 0.078364 & 2.193 & 0.0579 \\
\hline DLCPI_1 & 0.21653 & 0.095376 & 2.270 & 0.0252 \\
\hline ECM_1 & -0.17507 & 0.031251 & -2.831 & 0.0056 \\
\hline Constant & 0.0065817 & 0.0021683 & 3.035 & 0.0030 \\
\hline Seasonal (q1) & -0.11957 & 0.061757 & -1.936 & 0.0556 \\
\hline Seasonal (q2) & 0.0052192 & 0.0023792 & 2.194 & 0.0306 \\
\hline Seasonal (q3) & 0.0016100 & 0.0056014 & 0.287 & 0.7743 \\
\hline
\end{tabular}

Single Equations Diagnostic Tests ( $\mathrm{p}$-values in parenthesis):

Error auto-correlation $=1.410556$ [0.225945];

$\mathrm{ARCH}=1.112056$ [0.3512487]; Heteroskedasticity $=1.928751$ [01105687]

Systems Tests ( $\mathrm{p}$-values in parenthesis):

Error auto-correlation $=0.60462587$ [0.69652784];

$\mathrm{ARCH}=1394587524[0.233358974] ;$ Heteroskedasticity $=1.232225687[0.30052845671]$

In each ECM equation, the coefficient of the own error correction term should be negative, that is, the dependent variable should vary in the opposite direction of the error, the deviation from equilibrium. This ensures that the model will correct the deviation from equilibrium; otherwise the system would never converge to equilibrium following a shock. The deviations from the cointegrating relationships measured by $E C M_{t}$ are statistically significant, see Tables $4 \mathrm{a}, 4 \mathrm{~b}$ and $4 \mathrm{c}$. The coefficients are correctly signed and therefore provide support for the validity of the cointegrating relationship estimated, which lies between 15 percent and 20 percent 
for sample 1970q1-2015q4 and sub-sample 2000q1-2015q4. For the post-inflation targeting sub-period (2000q1 to 2015q4), approximately 20 percent of the previous disequilibrium in import prices is corrected each quarter, while for the pre-inflation targeting period (1970q1-1999q4), only approximately 18 percent of previous disequilibrium is eliminated each quarter. Thus, the speed of adjustment is higher for the post-inflation targeting sub-period.

Table 4c: Estimates of the Adjustment to Long Run Equilibrium Relationships- 2000q1 to 2015q4(Dependent Variable: Change in Log of CPI)

\begin{tabular}{lrrrr}
\hline Data: 2000q1 to 2015q4 & & & & \\
\hline Variable & Coefficient & Std. Error & t-value & t-prob \\
\hline DLIMP_1 & 0.144678 & 0.067549 & 3.0120 & 0.0026590 \\
DLIR_2 & -0.373456 & 0.058976 & -4.12089 & 0.002675 \\
DLER_3 & 0.317865 & 0.056898 & 2.06759 & 0.006758 \\
DLIP_1 & 0.17132 & 0.05098 & 2.1788 & 0.005466 \\
DLCPI_3 & 0.097856 & 0.026678 & 4.30908 & 0.001328 \\
ECM_1 & -0.196768 & 0.0367589 & -3.65784 & 0.0033433 \\
Constant & 0.06564 & 0.0117958 & 4.6884 & 0.0000001 \\
Seasonal (q1) & -0.022356 & 0.034744 & -1.98932 & 0.0365780 \\
Seasonal (q2) & 0.035879 & 0.032922 & 2.07812 & 0.0277652 \\
Seasonal (q3) & 0.0026168 & 0.0602340 & 1.98714 & 0.0545327 \\
\hline Sing
\end{tabular}

Single Equations Diagnostic Tests (p -values in parenthesis):

Error auto-correlation $=1.1673354$ [0.232286761];

ARCH $=1.9196679[0.11132684] ;$ Heteroskedasticity $=0.90569867$ [0.62470291]

Systems Tests ( $\mathrm{p}$-values in parenthesis):

Error auto-correlation $=1.56354904[0.236796247]$;

$\mathrm{ARCH}=1.27652510[0.08896846] ;$ Heteroskedasticity $=1.202425798[0.0786418091]$

Therefore, based on the coefficient of -0.38 for subsample import prices shown in Table $5 \mathrm{a}$, when import prices exceed their long run relationship with the trading partners' production costs and the exchange rate, they adjust downwards at a rate of 38 percent each quarter. The lower the coefficient, the longer it takes for import prices to adjust to their long run equilibrium level and vice versa. Also, the contemporaneous response of domestic prices to the exchange rate shocks in the post-inflation targeting period is positive and significant which means that the depreciation of exchange rate leads to an increase in the rate of inflation. The results in Tables $4 \mathrm{a}$ and $4 \mathrm{~b}$ suggest that a 10 percent depreciation of the exchange rate will increase the inflation rate by 4.3 percent and 4.2 percent respectively, which is higher than the 3.2 percent for the post inflation-targeting period. This implies that South Africa experienced higher inflation rates before the introduction of inflation targeting by the South African Reserve Bank. As also discussed in Section 3, strategic behavior in the form of pricing-to-market may explain why exchange rate fluctuations are not fully reflected in domestic prices ${ }^{22}$. Further, the results show that the impact of foreign prices on domestic prices is positive as well as significant, but higher for the entire period than for the subperiods. Also, the producers' prices seem to influence the local currency prices of imports in South Africa.

The paper explores the Impulse Response Function (IRF) and the Variance Decomposition (VDC). In general, the IFR refers to the reaction of the dynamic system in response to some external change while the VDC refers to the breakdown of the forecast error variance for a specific time horizon. It shows which variable has short term or long-term impacts on another variable of interest, especially the percentage of the fluctuation in a time series that is attributable to other variables at select time horizons.

The results in Table 5 show the responses of domestic prices to a one percent shock in the exchange rate after 3, 6, 12 and 24 months. It is apparent that import prices respond quickly to an exchange rate shock.

Table 5: Effect of a One Percent Change in Exchange Rate on Domestic Price Indices

\begin{tabular}{lrrrr}
\hline & After 3 Months & After 6 Months & After 12 Months & After 24 Months \\
\hline Import prices & 0.199 & 0.445 & 0.523 & 0.575 \\
Consumer prices & 0.059 & 0.161 & 0.246 & 0.249 \\
\hline
\end{tabular}

After one quarter, about 20 percent of an exchange rate shock had been passed on to import prices, and after four quarters, 56 percent had been passed on. On the other hand, after four quarters, only 23 percent of an exchange rate change had been passed on to domestic prices in South Africa. In the short run, consumer prices respond only gradually to exchange rate changes and It is observed that less than 24 percent of an exchange rate shock is passed on to consumer prices in the long run.

\footnotetext{
${ }^{22}$ Krugman (1987) and Dornbusch (1987) show that under imperfect competition 'pricing-to-market' may explain why fluctuations in the exchange rate are not reflected one-for-one in prices.
} 
Figure 2: Response of domestic price indices to a one percent exchange rate shock

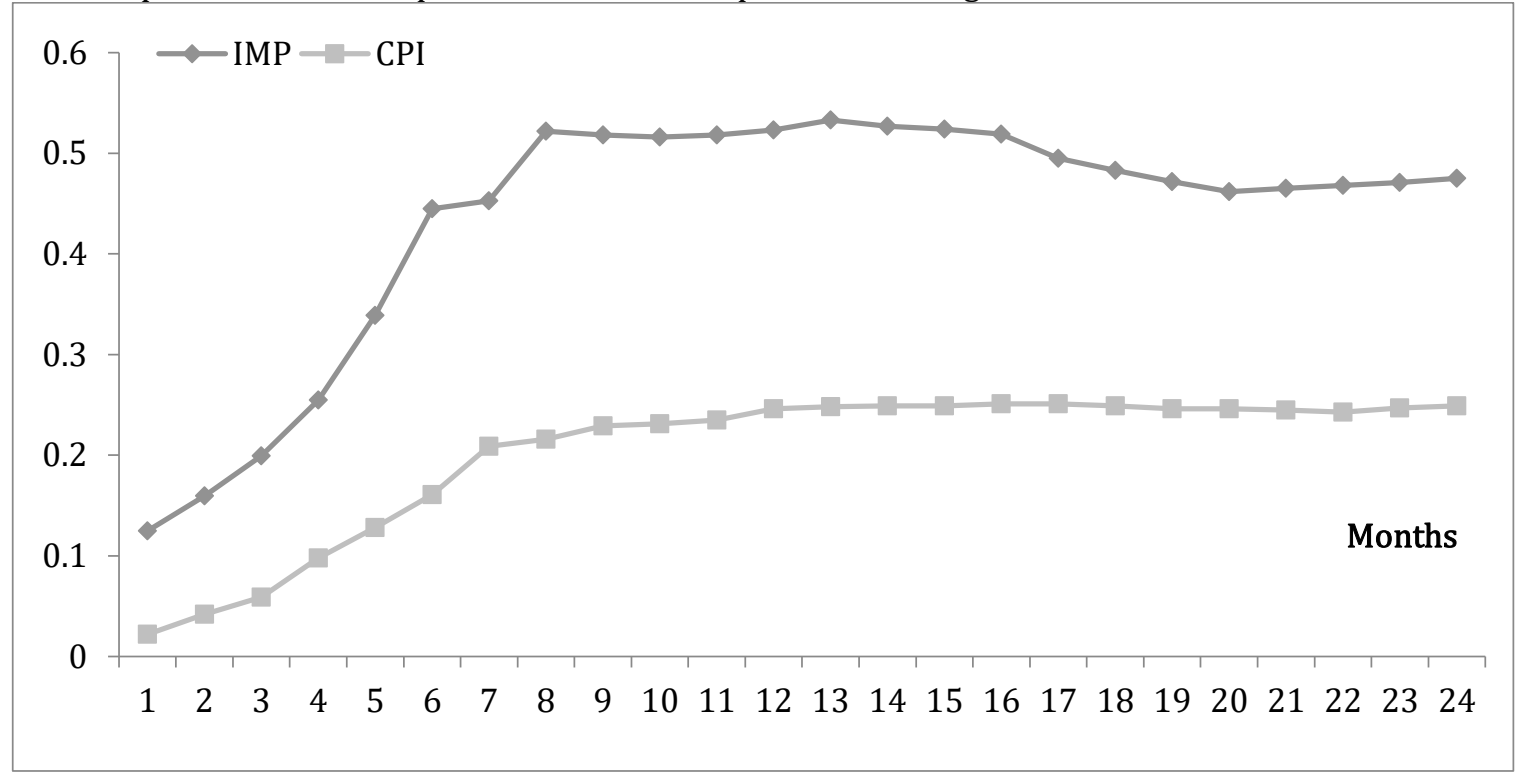

\section{Conclusion}

This paper researched the impact of inflation targeting on exchange rate pass-through to domestic prices in South Africa using quarterly data from 1970q1 to 2015q4. Applying a VAR model, the results show that inflation targeting has significant impacts on the movements of inflation, output and the exchange rate. The pass-through to consumer prices decreased and there also was a reduction in the influence of foreign producer costs on imports prices after the adoption of inflation targeting. The decrease in pass-through effect may imply that after the adoption of inflation targeting in South Africa, retailing firms that import goods from abroad absorb a larger fraction of an exchange rate shock through a smaller variation in their selling prices. So also, firms that import their inputs from abroad absorb a larger fraction of an exchange rate shock through a smaller variation in the prices of their final products.

Further, the results suggest that the South African Reserve Bank's commitment to low inflation is an important factor in achieving desired levels of exchange rate pass-through and volatility. In fact, the adoption of the IT framework continues to strengthen the SARB's mandate to focus on price stability. To achieve its objective, the Bank may also have to resort to foreign exchange intervention and capital controls in response to exchange rate shocks so as to mitigate the impact of exchange rate pass-through effects on inflation and also to reduce exchange rate volatility. The recent increase in the inflation rate may suggest that the SARB has become more tolerant toward higher levels of inflation to better support economic activity in the face of an extremely challenging global environment.

\section{References}

Akofio-Sowah, Naa A. (2009) Is There a Link Between Exchange Rate Pass-Through and the Monetary Regime: Evidence from Sub-Saharan Africa and Latin America International Advances in Economic Research 15:3, 296-309.

Athukorala, P. and Menon, J. (1994) Pricing to Market Behavior and Exchange Rate Pass-Through in Japanese Exports Economic Journal 104:423, 271-281.

Atta, J.K., Jefferis, K.R and Mannathoko, I. (1996) Small Country Experiences with Exchange Rates and Inflation: The Case of Botswana. Journal of African Economies 5:2, 293-326.

Ball, L. and Sheridan, N. (2005) Does Inflation Targeting Matter? In the Inflation-Targeting Debate, edited by B. S. Bernanke and M. Woodford, pp. 249-276. University of Chicago Press.

Bernanke, Ben S. and Mishkin, Frederic S. (1997) Inflation Targeting: A New Framework for Monetary Policy? Journal of Economic Perspectives 11:2, 97-116.

Bhundia, Ashok (2002) An Empirical Investigation of Exchange Rate Pass-Through in South Africa. Working Paper 02/165, International Monetary Fund.

Campa, Jose and Goldberg, Linda (2005) Exchange Rate Pass-Through into Imports Prices. Review of Economics and Statistics 87:4, 679-690.

Choi, Woon G. and Cook, David (2008) New Keynesian Exchange Rate Pass-Through Working Paper 08/213, International Monetary Fund. 
Coulibaly, D. and Kempf, H. (2010) Does Inflation Targeting Decrease Exchange Rate Pass-Through in Emerging Countries? Documents de travail du Centre d'Economie de la Sorbonne 10049, Université PanthéonSorbonne (Paris 1), Centre d'Economie de la Sorbonne.

Devereux, M.B. and Yetman, J. (2003) Price Setting and Exchange Rate Pass-Through: Theory and Evidence. Price Adjustment and Monetary Policy. Bank of Canada.

Dornbusch, R. (1987) Exchange Rate and Prices. American Economic Review 77:1, 93-106.

Ecevit, Eyyup and Kayhan, Selim (2011) Impact of Exchange Rate on Monetary Policy Decisions in An Inflation Targeting Regime: SVAR Analysis, Journal of Money, Investment and Banking 19, 114-123.

Feenstra, R.C. (1989) Symmetric Pass-Through of Tariffs and Exchange Rates under Imperfect Competition: An Empirical Test. Journal of International Economics 27:1-2, 25-45.

Feinberg, R.M. (1989) The Effects of Foreign Exchange Movements on US Domestic Prices. Review of Economics and Statistics 71:3, 505-511.

Gagnon, J. and Ihrig, J. (2004) Monetary Policy and Exchange Rate Pass-Through. International Journal of Finance and Economics 9:4, 315-338.

Gagnon, J. and Knetter, M. (1991) Pricing to Market in Response to Unobservable and Observable Shocks. Darthmouth College WP 89:16.

Giovannini, A. (1988) Exchange Rate and Goods Prices Journal of International Economics 24:1-2, 45-68.

Goldberg, P. K. and Knetter, M. (1997) Goods Prices and Exchange Rate: What Have We Learned? Journal of Economic Literature 35:3, 1243-1272.

Hahn, E. (2003) Pass-Through of External Shocks to Euro Area Inflation Working Paper 243, European Central Bank.

Helpman, E. (1981) An Exploration in the Theory of Exchange Rate Regimes. Journal of Political Economy 89:5, 865-890.

Hooper, P. and Mann, C.L. (1989) Exchange Rate Pass-Through in the 1980s: The Case of U.S. Imports of Manufactures. Brookings Papers on Economic Activity 1989:1, 297-337.

International Financial Statistics (2015) A publication of the International Monetary Fund, Washinton, DC.

Isard, P. (1977) How Far Can We Push the Law of One Price? American Economic Review 67:5, 942-948.

Ito, Takatoshi and Sato, Kiyotaka (2007) Exchange Rate Pass-Through and Domestic Inflation: A Comparison Between East Asia and Latin American Countries Discussion Papers 07040, Research Institute of Economy, Trade and Industry (RIETI).

Karagoz, Demirel and Bozdag (2016) Pass-through effect from Exchange rate to the prices in the Framework of Inflation Targeting Policy: A Comparison of Asia-Pacific, South American and Turkish Economies

Karoro, T.D., Aziakpono, M.J. and Cattaneo, N. (2009) Exchange Rate Pass-through to Import Prices in South Africa: Is There Asymmetry? South African Journal of Economics 773:3, 380-398.

Khemiri, R. and Ali, M.S.B. (2012) Exchange Rate Pass-Through and Inflation Dynamics in Tunisia: A MarkovSwitching Approach Discussion Paper, Kiel Institute for the World Economy, No. 2012-39.

Khodeir, Aliaa N. (2012) Towards Inflation Targeting in Egypt: The Relationship between Exchange Rate and Inflation. South African Journal of Economics and Management Sciences 15:3, 325-332.

Kim, Y. (1990) Exchange Rates and Import Prices in the U.S.: A Varying Parameter Estimation of Exchange Rate Pass-Through. Journal of Business and Economic Statistics 8:3, 305-315.

Knetter, M. (1989) Price Discrimination by US and German Exporters American Economic Review 79:1, 198-210.

Knetter, M. (1993) International Comparisons of Pricing-to-Market Behavior. American Economic Review 83:3, 423-436.

Kravis, R.B. and Lipsey, R.E. (1977) Export Prices and the Transmission of Inflation American Economic Review 67:1, 155-163.

Krugman, Paul, (1979) A Model of Balance-of-Payments Crises Journal of Money, Credit and Banking 11:3, 311325.

Krugman, P. (1987) Pricing to Market when the Exchange Rate Changes, in Real-Financial Linkages among Open Economies, eds.: Sven, W. and Richardson, J.D. MIT Press, 49-70.

Krugman, P. and Obstfeld, M. (1994) International Economics. Boston: Scott, Foresman/Little Brown.

Lancaster, Kelvin (1980) Intra-industry Trade under Perfect Monopolistic Competition Journal of International Economics 10:2, 151-175.

Liu, H. Y and Chen, X. L (2017) The Imported Price, Inflation and Exchange rate pass-through in China, Cogent Economic and Finance, Vol. 5

Marston, R.C. (1990) Pricing to Market in Japanese Manufacturing Journal of International Economics 29, 217 236.

McCarthy J. (2007) Pass-Through of Exchange Rates and Import Prices to Domestic Inflation in Some Industrialized Economies Eastern Economic Journal 33:4, 511-537.

Menon, J. (1995a) Exchange Rate and Import prices for a Small Open Economy. Applied Economics 27:3, 297-301.

Menon, J. (1995b) Exchange Rate Pass-Through. Journal of Economic Surveys 9:2, 197-231. 
Menon, J. (1996) The Degree and Determinants of Exchange Rate Pass-through: Market Structure, Non-tariff Barriers and Multinational Corporations, Economic Journal 106:435, 434-444.

Mihaljek, D. and Klau, M. (2007) The Balassa-Samuelson Effect and the Maastricht Criteria: Revisiting the Debate. In N. Batini (ed), Monetary Policy in Emerging Markets and Other Developing Countries New York: Nova Science Publishers.

Mishkin, F.S. and Schmidt-Hebbel, K. (2007) A Decade of Inflation Targeting in the World: What Do We Know and What Do We Need to Know? In F.S. Mishkin: Monetary Policy Strategy, M.I.T. Press, Cambridge, MA.

Mwase, N. (2006) An Empirical Investigation of the Exchange Rate Pass-Through to Inflation in Tanzania, Working Paper No. 06/150, International Monetary Fund.

Naqvi, Bushra and Rizvi, Syed K. A. (2012) What Does Pakistan Have to Join the Inflation Targeters' Club-A Royal Flush or a Seven-Deuce Offsuit? The Lahore Journal of Economics 17:2, 35-62.

Nell, K. (2000) Imported Inflation in South Africa: An Empirical Study Studies in Economics 0005, Department of Economics, University of Kent.

Nogueira Jr., Reginaldo P. (2007) Inflation Targeting and Fear of Floating. Paper presented at Money Macro and Finance (MMF) Research Group Conference 2007.

Odria, L.R., Castillo P. and Rodriguez, G. (2012) Does the Exchange Rate Pass Through into Prices Change When Inflation Targeting is Adopted? The Peruvian Case Study between 1994 and 2007. Journal of Macroeconomics 34:4, 1154-1166.

Phillips, R.W. (1988) The Pass-Through of Exchange Rate Changes to Prices of Imported Manufactures. Discussion Paper 197, Centre for Economic Policy Research, Australian National University, Canberra.

Prasertnukul, W., Kim, D. and Kakinaka, M. (2010) Exchange Rates, Price Levels, and Inflation Targeting: Evidence from Asian Countries Japan and the World Economy 22:3, 173-182.

Razafimahefa, Ivohasina F. (2012) Exchange Rate Pass-Through in Sub-Saharan African Economies and its Determinants. Working Paper, WP/12/2141 International Monetary Fund.

Reyes, J. (2007) Exchange Rate Pass-Through Effect and Inflation Targeting in Emerging Economies: What is the Relationship? Review of International Economics 15:3, 538-559.

Richardson, J.D. (1978) Some Empirical Evidence on Commodity Arbitrage and the Law of One Price, Journal of International Economics 8:2, 341-351.

Roger, S. and Stone, M. (2005) On Target? The International Experience with Achieving Inflation Targets. Working Paper 05/163 International Monetary Fund.

Rogoff, Kenneth (1996) The Purchasing Power Parity Puzzle. Journal of Economic Literature 34:2, 647-668.

Saha, Shrabani and Zhang, Zhaoyong (2012) Exchange Rate Pass-Through and Its Impact on Inflation: A Comparative Study for Australia, China and India with Disaggregated Data, Edith Cowan University, School of Accounting, Finance and Economics

Sek, S.K, Ooi, C.P. and Ismail, M.T (2012) Investigating the Relationship between Exchange Rate and Inflation Targeting. Applied Mathematical Sciences 6:32, 1571-1583.

South African Reserve Bank, (2002) Exchange Rate Pass-Through and South African Import Prices. SARB Working Paper WP/02/03. Pretoria: South Africa.

Taguchi, H. and Sohn, W.-K. (2014), Inflation Targeting and the Pass-through Rate in East Asian Economies. Asian Economic Journal, 28:2, 139-159. doi: 10.1111/asej.12029.

Taylor, J.B. (2000) Low Inflation, Pass-Through, and the Pricing Power of Firms. European Economic Review 44:7, 1389-1408.

Winkelried, Diego (2014) Exchange Rate Pass-Through and Inflation Targeting in Peru Empirical Economics 46:4, 1181-1196. 